\title{
Mitochondria-Immobilized Unimolecular Fluorescent Probe for Multiplexing Imaging of Living Cancer Cells
}

Nansong Zhu, ${ }^{\dagger}$ Xiaolei Guo, ${ }^{\dagger}$ Shirui Pang, ${ }^{\dagger}$ Yulei Chang, ${ }^{*},{ }^{\dagger}$ Xiaomin Liu,${ }^{\S}$ Zhan Shi, ${ }^{*},{ }^{\dagger}$ Shouhua Feng ${ }^{\dagger}$

${ }^{\dagger}$ State Key Laboratory of Inorganic Synthesis and Preparative Chemistry, College of Chemistry, Jilin University, Changchun 130012, P. R. China; Email: zshi@mail.jlu.edu.cn

State Key Laboratory of Luminescence and Applications, Changchun Institute of Optics, Fine Mechanics and Physics, Chinese Academy of Sciences, Changchun 130033, China; Email: yuleichang@ciomp.ac.cn

${ }^{\S}$ State Key Laboratory of Integrated Optoelectronics, College of Electronic Science and Engineering, Jilin University, Changchun 130012, China

\section{Table of Contents}

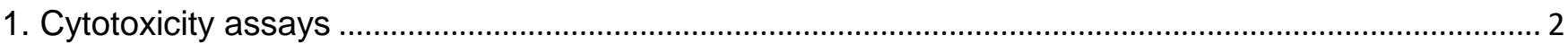

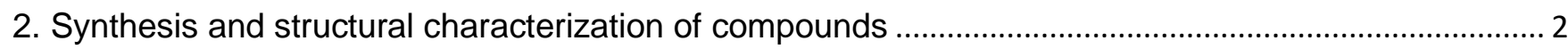

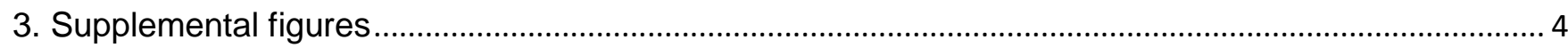




\section{Cytotoxicity assays}

Cells were cultured in DMEM supplemented with 10\% FBS at $37^{\circ} \mathrm{C}$ under an atmosphere of $5 \% \mathrm{CO}_{2}$. Cells were then inoculated in 96-well plates and cultured overnight. After that, cells were treated with PBS buffers (10 mM, pH 7.4, 0.1\% DMSO) containing $5 \mu \mathrm{M}$ ZED for $10 \mathrm{~min}$. The control groups were treated with only PBS buffers (10 mM, pH 7.4, 0.1\% DMSO) for $10 \mathrm{~min}$. PBS buffers were then replaced by complete medium, and cells were allowed to grow for another $12 \mathrm{~h}$. After that, cell viability was measured by CCK-8. The absorbance at $450 \mathrm{~nm}$ was measured with a microplate reader. Optical density (OD) of the 12 wells in the indicated groups was used to calculate the percentage of cell viability according to the formula below:

Percentage of cell viability $=$ OD treatment group / OD control group $\times 100 \%$

\section{Synthesis and structural characterization of compounds}

Scheme S1. Synthesis route of 4 .

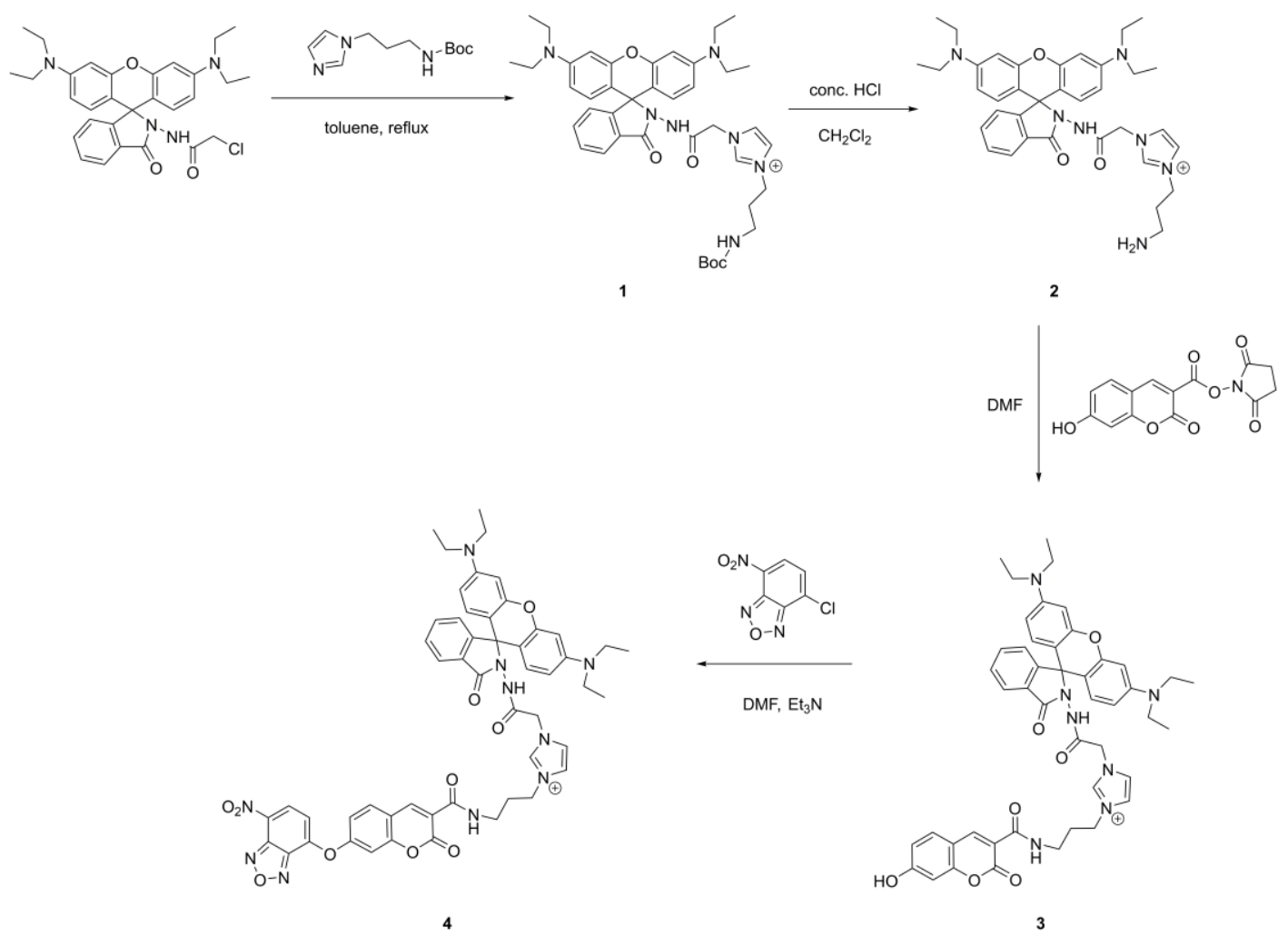

Synthesis of 1. A mixture of $\mathrm{N}$-[3',6'-Bis(diethylamino)-3-oxospiro[1H-isoindole-1,9'-[9H]xanthen]2(3H)-yl]-2-chloroacetamide (400 mg, $0.75 \mathrm{mmol})$ and tert-Butyl[3-(1H-imidazol-1-yl)propyl]carbamate (282 mg, $1.25 \mathrm{mmol}$ ) in $5 \mathrm{~mL}$ toluene was refluxed at $120{ }^{\circ} \mathrm{C}$ overnight. After the reaction was stopped, 
the toluene solution was removed under vacuum condition and the residue was subjected on flash column chromatography. The mixture was purified with eluents of $\mathrm{CH}_{2} \mathrm{Cl}_{2}$ and $\mathrm{CH}_{3} \mathrm{OH}$. Yield $(376 \mathrm{mg}$, $65 \%) .{ }^{1} \mathrm{H}$ NMR $\left(400 \mathrm{MHz}\right.$, DMSO- $\left.d_{6}\right) \delta=10.29(\mathrm{~s}, 1 \mathrm{H}), 9.13(\mathrm{~s}, 1 \mathrm{H}), 7.84-7.72(\mathrm{~m}, 2 \mathrm{H}), 7.64-7.50(\mathrm{~m}$, 2H), $7.39(\mathrm{t}, J=1.8,1 \mathrm{H}), 7.07-6.95(\mathrm{~m}, 2 \mathrm{H}), 6.51(\mathrm{~d}, J=8.6,2 \mathrm{H}), 6.34(\mathrm{~d}, J=9.2,3 \mathrm{H}), 5.01(\mathrm{~s}, 2 \mathrm{H})$, 4.19 (t, $J=7.0,2 \mathrm{H}$ ), 3.35-3.26 (m, 8H), 2.91 (q, $J=6.4,2 \mathrm{H}), 1.87$ (p, $J=6.8,2 \mathrm{H}), 1.38(\mathrm{~s}, 9 \mathrm{H}), 1.08$ (t, $J=6.9,12 \mathrm{H}) ;{ }^{13} \mathrm{C}$ NMR $\left(100 \mathrm{MHz}\right.$, DMSO- $\left.d_{6}\right) \delta=164.62,164.02,156.13,153.44,152.36,148.91$, 137.82, 134.01, 129.54, 129.03, 128.33, 124.37, 123.83, 123.19, 122.44, 108.20, 104.38, 97.55, 78.25, 65.57, 49.71, 47.19, 44.12, 36.97, 30.52, 28.70, 12.92; LC-HRMS m/z $722.4007[\mathrm{M}+\mathrm{H}]^{+}$; calcd for $\mathrm{C}_{41} \mathrm{H}_{52} \mathrm{~N}_{7} \mathrm{O}_{5}: 722.4024$.

Synthesis of 2. Compound 1 ( $555 \mathrm{mg}, 0.73 \mathrm{mmol}$ ) was dissolved in $10 \mathrm{~mL} \mathrm{CH} \mathrm{Cl}_{2}$ and then $0.5 \mathrm{~mL}$ concentrated hydrochloric acid was added. The mixture was further stirred for $1 \mathrm{~h}$ at room temperature. After the reaction was stopped, $\mathrm{Et}_{3} \mathrm{~N}$ was added. The mixture was diluted by $\mathrm{CH}_{2} \mathrm{Cl}_{2}$ and washed by brine. The organic phase was then dried by anhydrous $\mathrm{Na}_{2} \mathrm{SO}_{4}$ and the solvent was removed under vacuum condition. Yield $(410 \mathrm{mg}, 85 \%)$. The crude product was used without further purification.

Synthesis of 3. Compound $2(412 \mathrm{mg}, 0.63 \mathrm{mmol})$ was dissolved in $12 \mathrm{~mL}$ DMF and then (2,5Dioxopyrrolidin-1-yl)7-hydroxy-2-oxochromene-3-carboxylate (228 $\mathrm{mg}, 0.75 \mathrm{mmol}$ ) was added. After that, a few drops of $\mathrm{Et}_{3} \mathrm{~N}$ were added and the mixture was stirred at room temperature overnight. After the reaction was stopped, DMF was removed under vacuum condition at $45{ }^{\circ} \mathrm{C}$. The residue was purified by flash column chromatography with eluents of $\mathrm{CH}_{2} \mathrm{Cl}_{2}$ and $\mathrm{CH}_{3} \mathrm{OH}$. Yield $(370 \mathrm{mg}, 79 \%)$. ${ }^{1} \mathrm{H}$ $\operatorname{NMR}\left(400 \mathrm{MHz}, \mathrm{DMSO}-d_{6}\right) \delta=10.28(\mathrm{~s}, 1 \mathrm{H}), 9.14(\mathrm{~d}, J=1.7,1 \mathrm{H}), 8.76(\mathrm{~s}, 1 \mathrm{H}), 8.71(\mathrm{q}, J=5.6,1 \mathrm{H})$, 7.85-7.76 (m, 3H), 7.64-7.49 (m, 2H), $7.39(\mathrm{t}, J=1.8,1 \mathrm{H}), 7.08-6.98(\mathrm{~m}, 1 \mathrm{H}), 6.94(\mathrm{dd}, J=8.6,2.3$, $1 \mathrm{H}), 6.90(\mathrm{~d}, J=2.2,1 \mathrm{H}), 6.51(\mathrm{~d}, J=8.6,2 \mathrm{H}), 6.35(\mathrm{~d}, J=2.4,2 \mathrm{H}), 6.32(\mathrm{~d}, J=2.6,1 \mathrm{H}), 5.00(\mathrm{~s}, 2 \mathrm{H})$, $4.24\left(\mathrm{t}, J=7.0,2 \mathrm{H}\right.$ ), $3.32(\mathrm{~s}, 2 \mathrm{H}), 3.30(\mathrm{~d}, J=7.2,8 \mathrm{H}), 2.05(\mathrm{p}, J=6.8,2 \mathrm{H}), 1.08(\mathrm{t}, J=7.0,12 \mathrm{H}) ;{ }^{13} \mathrm{C}$ NMR $\left(100 \mathrm{MHz}\right.$, DMSO- $\left.d_{6}\right) \delta=164.59,164.44,164.02,162.49,161.32,156.72,153.44,152.34$, $148.91,148.51,137.83,134.01,132.34,129.54,129.04,128.34,124.36,123.80,123.20,122.46$, 114.95, 113.99, 111.41, 108.19, 104.37, 102.32, 97.54, 65.57, 49.71, 47.45, 44.11, 36.43, 30.19, 12.92; LC-HRMS m/z $810.3612[\mathrm{M}+\mathrm{H}]^{+}$; calcd for $\mathrm{C}_{46} \mathrm{H}_{48} \mathrm{~N}_{7} \mathrm{O}_{7}: 810.3610$.

Synthesis of 4. Compound $3(42.3 \mathrm{mg}, 0.05 \mathrm{mmol})$ was dissolved in $5 \mathrm{~mL} \mathrm{DMF}$ and then 4-Chloro-7nitrobenz-2-oxa-1,3-diazole ( $20 \mathrm{mg}, 0.1 \mathrm{mmol}$ ) was added. After that, a few drops of $\mathrm{Et}_{3} \mathrm{~N}$ were added and the mixture was stirred at room temperature overnight. After the reaction was stopped, DMF was removed under vacuum condition at $45{ }^{\circ} \mathrm{C}$. The residue was purified by preparative thin layer chromatography with eluents of $\mathrm{CH}_{2} \mathrm{Cl}_{2}$ and $\mathrm{CH}_{3} \mathrm{OH}$. Yield (11 mg, 22\%). ${ }^{1} \mathrm{H} \mathrm{NMR}\left(400 \mathrm{MHz}\right.$, DMSO- $\left.d_{6}\right) \delta=$ $10.25(\mathrm{~s}, 1 \mathrm{H}), 9.13(\mathrm{~d}, J=6.8,1 \mathrm{H}), 8.91(\mathrm{~s}, 1 \mathrm{H}), 8.79-8.67(\mathrm{~m}, 2 \mathrm{H}), 8.18(\mathrm{~d}, J=8.6,1 \mathrm{H}), 7.84-7.77$ $(\mathrm{m}, 2 \mathrm{H}), 7.65(\mathrm{~d}, J=2.4,1 \mathrm{H}), 7.60-7.47(\mathrm{~m}, 3 \mathrm{H}), 7.39(\mathrm{~d}, J=6.2,1 \mathrm{H}), 7.12(\mathrm{~d}, J=8.3,1 \mathrm{H}), 7.03(\mathrm{~d}, J$ $=7.4,1 \mathrm{H}), 6.50(\mathrm{~d}, J=8.8,2 \mathrm{H}), 6.33(\mathrm{~d}, J=9.6,3 \mathrm{H}), 5.00(\mathrm{~s}, 2 \mathrm{H}), 4.29-4.21(\mathrm{~m}, 2 \mathrm{H}), 3.35(\mathrm{~s}, 8 \mathrm{H})$, 
$3.30(\mathrm{~d}, J=3.4,2 \mathrm{H}), 2.06(\mathrm{q}, J=8.3,7.5,2 \mathrm{H}), 1.08(\mathrm{t}, J=6.9,12 \mathrm{H}) ;{ }^{13} \mathrm{C}$ NMR $\left(100 \mathrm{MHz}\right.$, DMSO- $\left.d_{6}\right) \delta$ $=164.60,164.03,161.89,160.31,158.13,156.73,155.69,153.44,152.38,151.34,148.91,147.29$, $145.95,145.03,138.20,137.83,135.47,134.02,132.99,132.39,132.18,129.54,129.04,128.31$, 124.37, 123.86, 123.19, 122.46, 118.96, 117.81, 117.08, 113.69, 111.44, 108.41, 108.20, 104.38, 97.55, 65.56, 49.71, 47.43, 44.11, 36.61, 30.06, 12.92. LC-HRMS m/z 973.3607 [M+H]+; calcd for $\mathrm{C}_{52} \mathrm{H}_{49} \mathrm{~N}_{10} \mathrm{O}_{10}: 973.3628$.

\section{Supplemental figures}

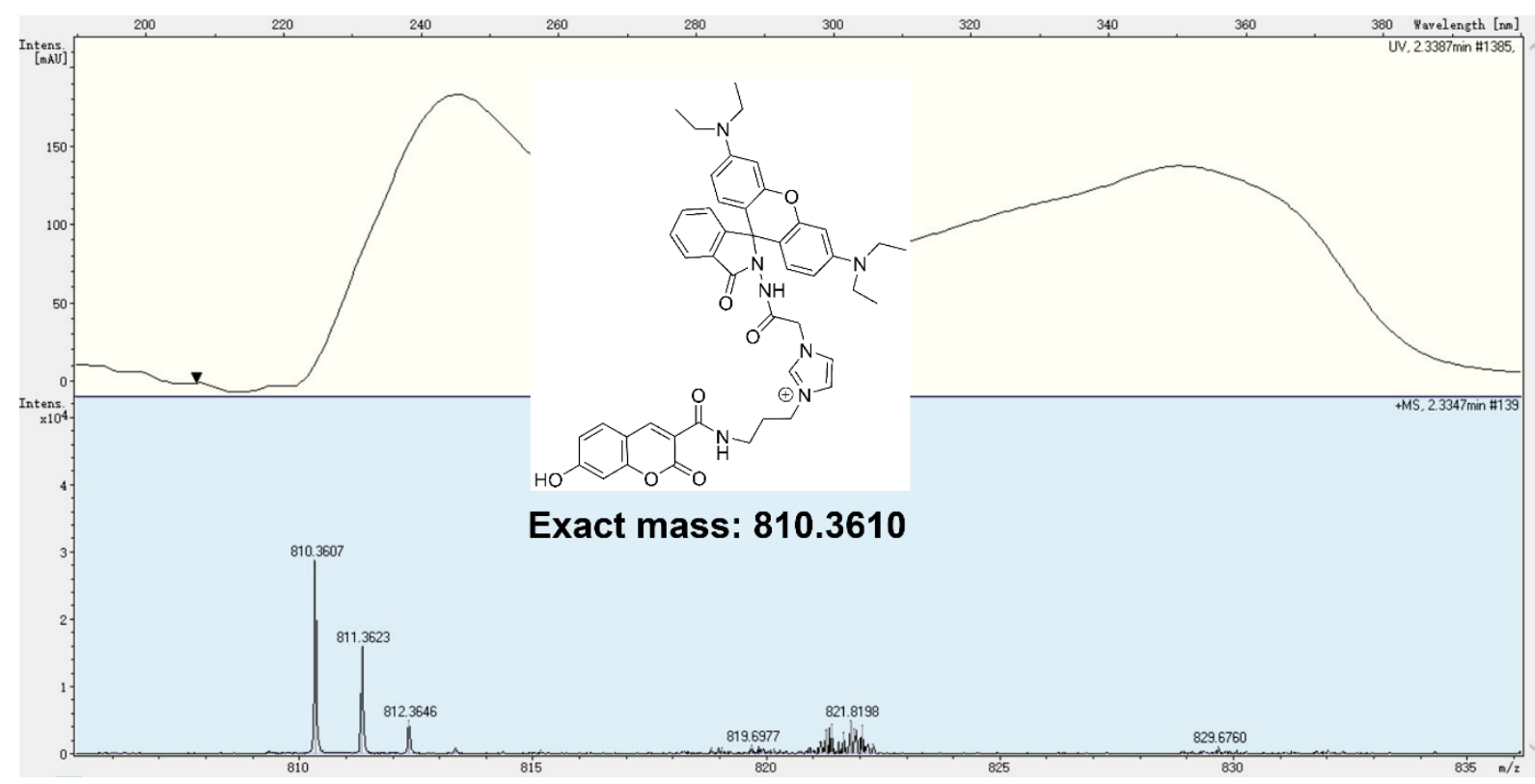

Figure S1. Mass spectrum of ZED-1 generated by the reaction of ZED and thiols. 


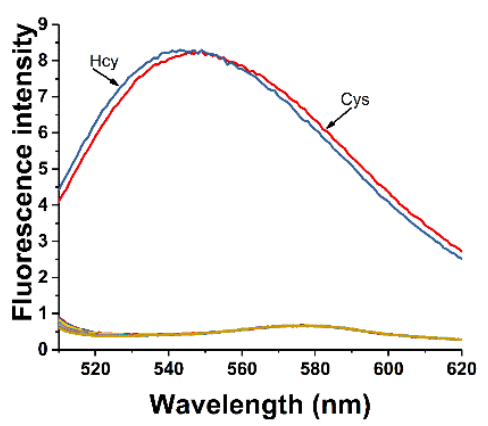

Figure S2. Fluorescence spectra of $5 \mu \mathrm{M}$ ZED in PBS buffers (pH 8.0) toward various analytes: 10 $\mu \mathrm{M}$ for ONOO, $\mathrm{HOCl}, \mathrm{H}_{2} \mathrm{O}_{2}, \mathrm{O}_{2}-{ }^{-}$t- $\mathrm{BuOOH}, \cdot \mathrm{OH},{ }^{1} \mathrm{O}_{2}, \mathrm{NO} ; 100 \mu \mathrm{M}$ for amino acids: Cys, Hcy, GSH, Val, Tyr, Trp, Ser, Pro, Lys, Leu, His, Gly, Glu, Asp, Asn, Arg, Ala; $100 \mu \mathrm{M}$ for $\mathrm{Na}^{+}, \mathrm{K}^{+}, \mathrm{Ca}^{2+}, \mathrm{Mg}^{2+}$, $\mathrm{Cu}^{2+}, \mathrm{Fe}^{2+}, \mathrm{Zn}^{2+}, \mathrm{Cl}^{-}, \mathrm{NO}_{2}-\mathrm{H}_{2} \mathrm{~S}, \mathrm{NO}_{3}^{-}$; excitation at $488 \mathrm{~nm}$.

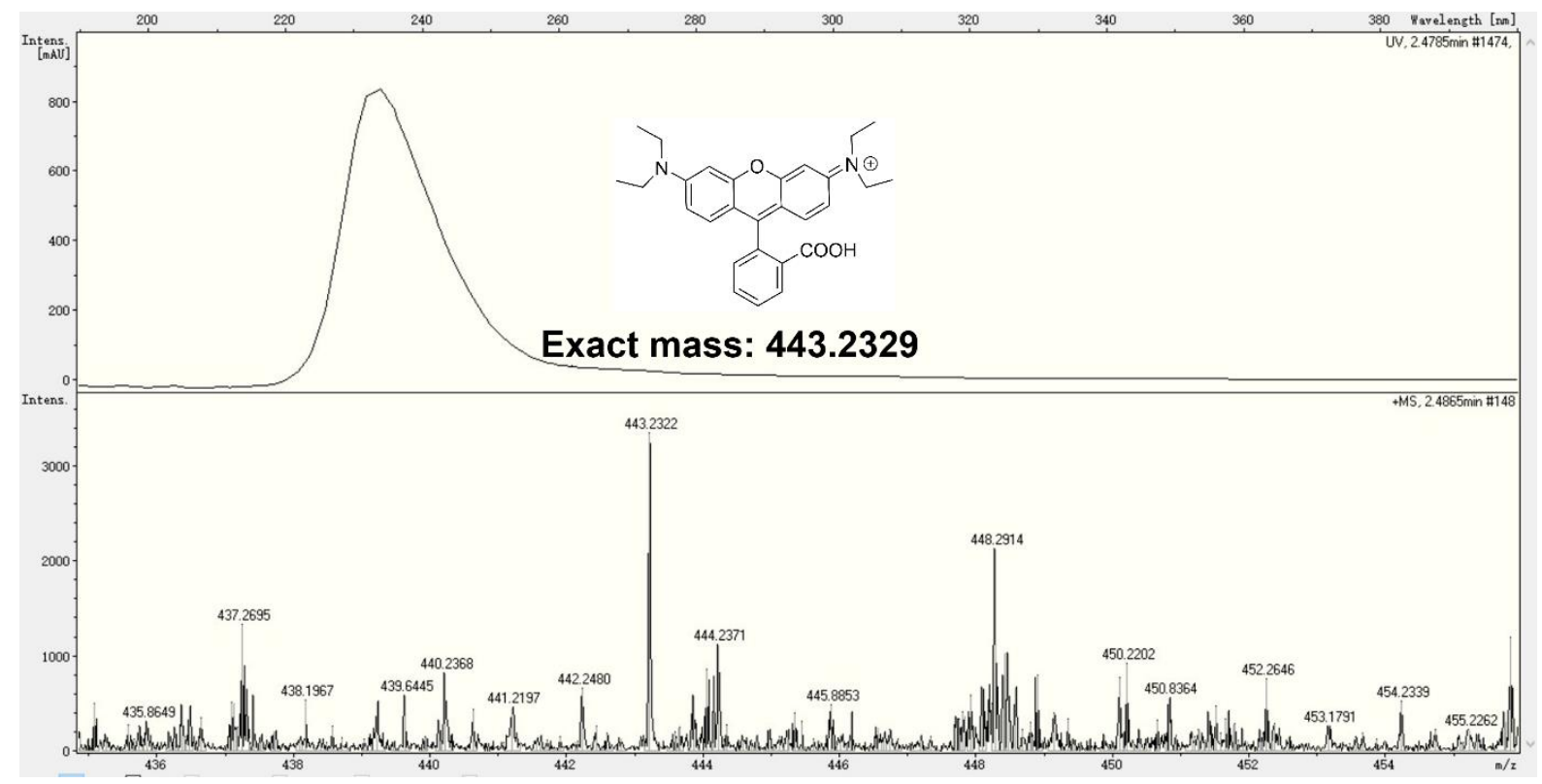

Figure S3. Mass spectrum of Rhodamine B generated by the reaction of ZED and $\mathrm{HOCl}$. 

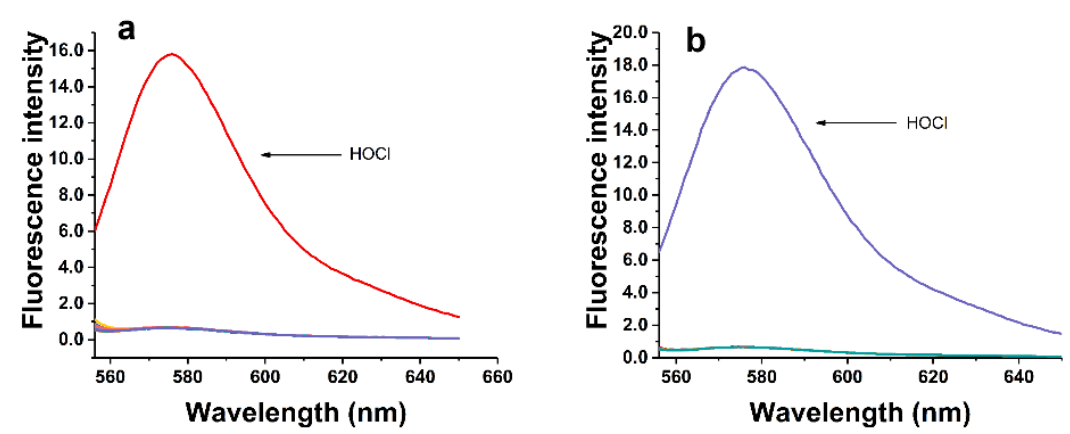

Figure S4. Fluorescence spectra of $5 \mu \mathrm{M}$ ZED (a) or ZED-1 (b) in PBS buffers (pH 8.0) toward various analytes: $10 \mu \mathrm{M}$ for $\mathrm{ONOO}^{-}, \mathrm{HOCl}, \mathrm{H}_{2} \mathrm{O}_{2}, \mathrm{O}_{2}^{--}$, t-BuOOH$, \cdot \mathrm{OH},{ }^{1} \mathrm{O}_{2}, \mathrm{NO} ; 100 \mu \mathrm{M}$ for amino acids: Cys, Hcy, GSH, Val, Tyr, Trp, Ser, Pro, Lys, Leu, His, Gly, Glu, Asp, Asn, Arg, Ala; $100 \mu \mathrm{M}$ for $\mathrm{Na}^{+}, \mathrm{K}^{+}, \mathrm{Ca}^{2+}, \mathrm{Mg}^{2+}, \mathrm{Cu}^{2+}, \mathrm{Fe}^{2+}, \mathrm{Zn}^{2+}, \mathrm{Cl}^{-}, \mathrm{NO}_{2}{ }^{-}, \mathrm{H}_{2} \mathrm{~S}, \mathrm{NO}_{3}^{-}$; excitation at $543 \mathrm{~nm}$.
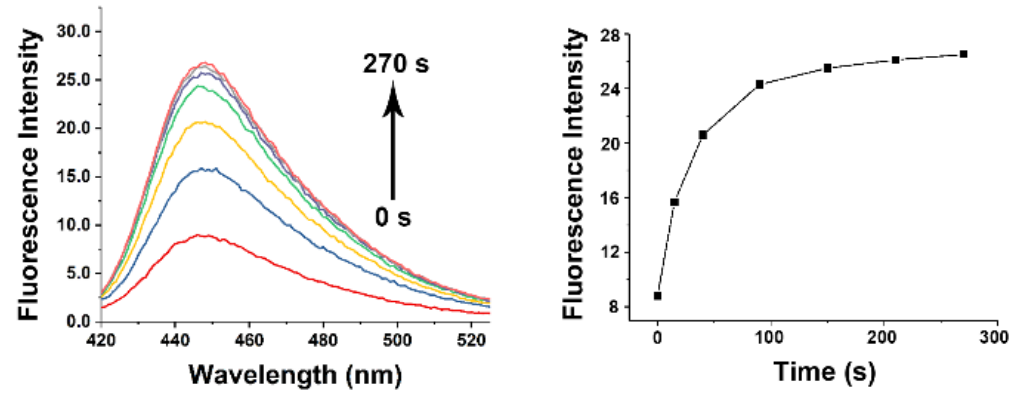

Figure S5. Fluorescent response of $5 \mu \mathrm{M}$ ZED to $2 \mathrm{mM} \mathrm{GSH}$ in PBS buffers (pH 8.0) at different time intervals (0-270 s), excitation at $405 \mathrm{~nm}$.

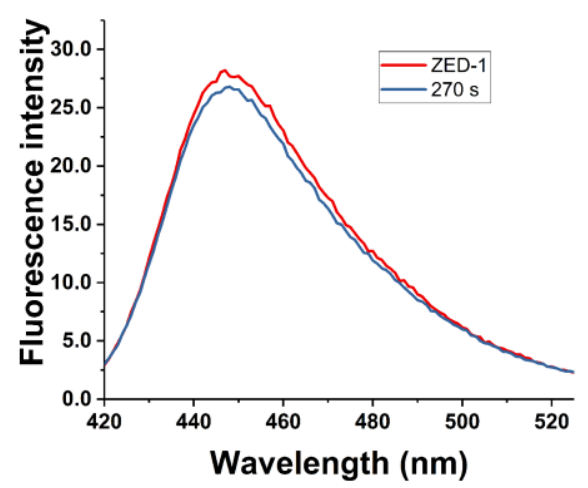

Figure S6. Fluorescence spectra of $5 \mu \mathrm{M}$ ZED-1 alone and the $F_{405}$ generated by the reaction of $5 \mu \mathrm{M}$ ZED and $2 \mathrm{mM} \mathrm{GSH}$ at $270 \mathrm{~s}$ in PBS buffers ( $\mathrm{pH} 8.0$ ), excitation at $405 \mathrm{~nm}$. 


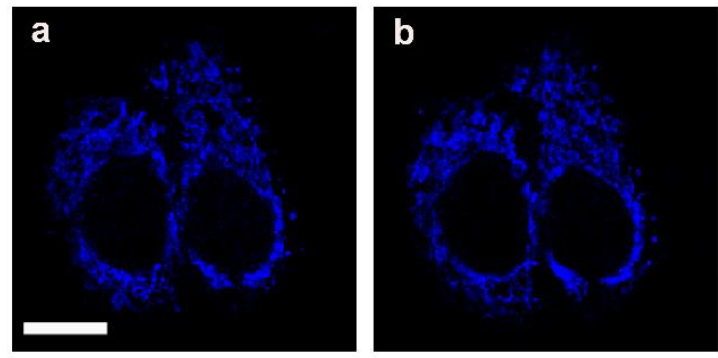

Figure S7. Confocal experiments involving ZED in MCF-7 cells. (a) Cells incubated with $5 \mu \mathrm{M}$ ZED for 10 min and then washed and recorded. (b) Cells from (a) further incubated for 15 min and then recorded. Images were recorded using excitation wavelength of $405 \mathrm{~nm}$, and band-path emission filter at 417-477 $\mathrm{nm}$. Scale bar: $10 \mu \mathrm{m}$.
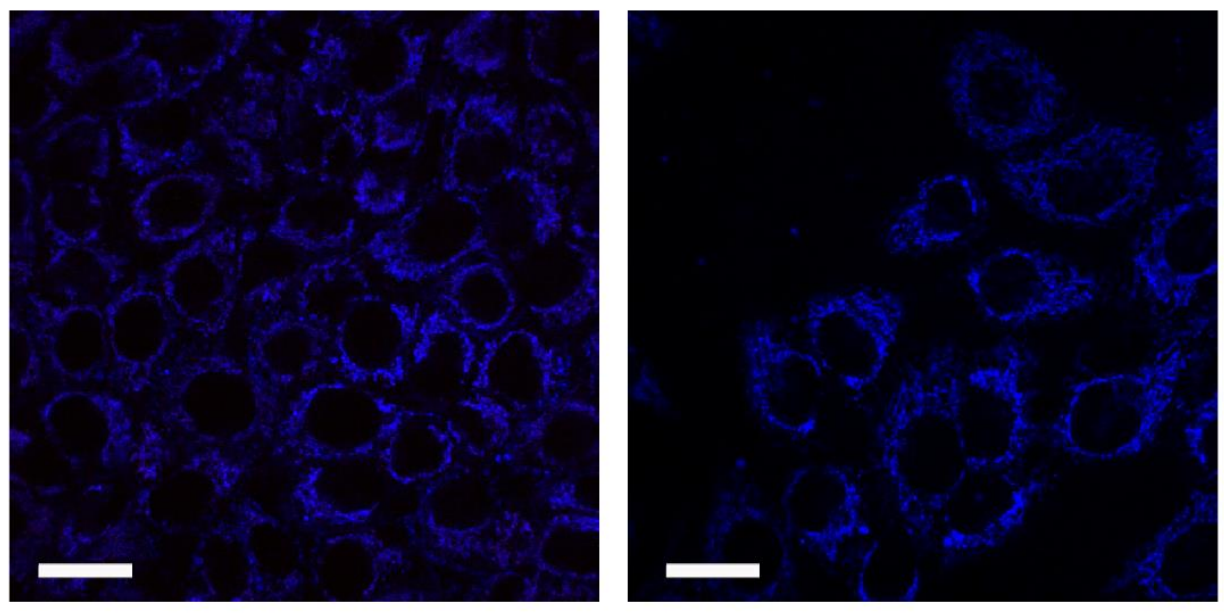

Figure S8. Repeated experiments to confirm the good cell permeability of ZED. MCF-7 cells incubated with $5 \mu \mathrm{M}$ ZED for $10 \mathrm{~min}$ and then washed and recorded. Images were recorded using excitation wavelength of $405 \mathrm{~nm}$, and band-path emission filter at 417-477 nm. Scale bar: $20 \mu \mathrm{m}$. 


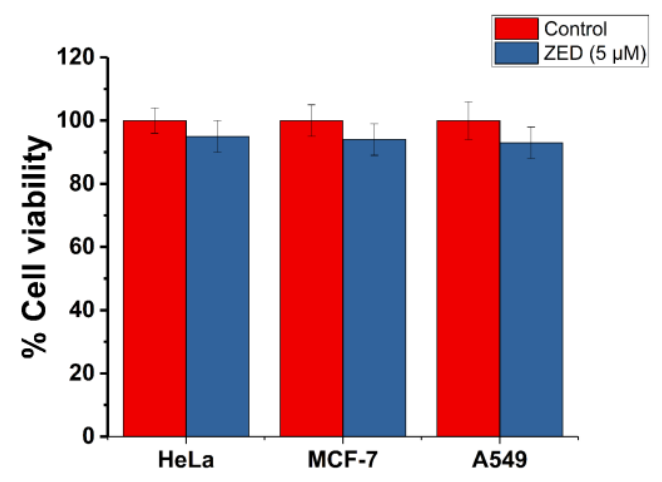

Figure S9. Cytotoxicity assays of $5 \mu \mathrm{M}$ ZED in different cells.

A
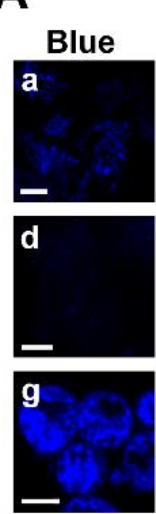

j
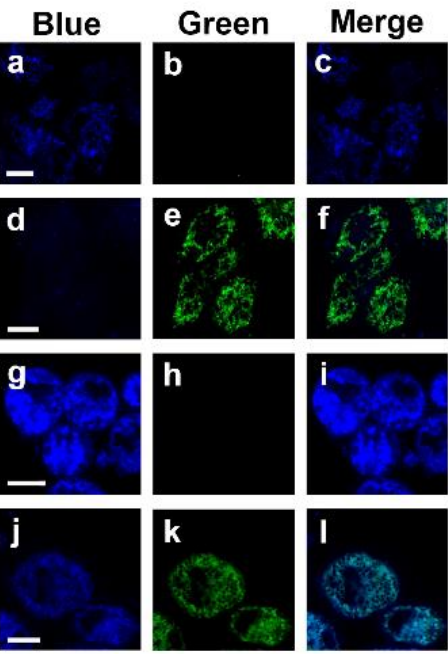

B
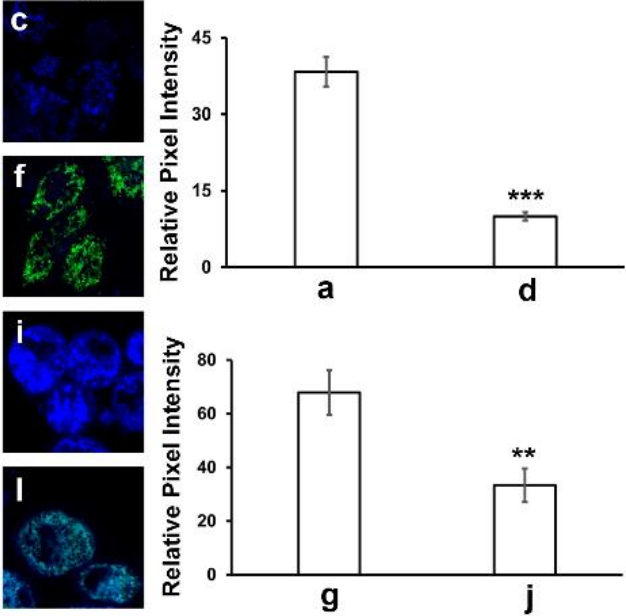

Figure S10. Fluorescence quenching experiments involving ZED and Mito-Tracker Green (MTG) in MCF-7 cells. (A) Images of the cells. (a-c) Cells incubated with $5 \mu M$ ZED for 10 min. (d-f) Cells incubated in sequence with $5 \mu \mathrm{M}$ ZED for $10 \mathrm{~min}$ and $1 \mu \mathrm{M}$ MTG for $10 \mathrm{~min}$. (g-i) Cells incubated in sequence with $5 \mu \mathrm{M}$ ZED for $10 \mathrm{~min}$ and $50 \mu \mathrm{M}$ CCCP for $2 \mathrm{~h}$. (j-l) Cells incubated in sequence with 5 $\mu \mathrm{M}$ ZED for $10 \mathrm{~min}, 1 \mu \mathrm{M}$ MTG for $10 \mathrm{~min}$, and $50 \mu \mathrm{M}$ CCCP for $2 \mathrm{~h}$. Blue and green channels were recorded using excitation wavelengths of 405 and $488 \mathrm{~nm}$, and band-path emission filters at 417-477 and 499-529 nm, respectively. (B) Relative pixel intensity of the related images in (A). The results are presented as mean \pm standard deviation $(\mathrm{n}=3)$. Significant differences $\left({ }^{\star \star} p<0.01 ;{ }^{* \star *} p<0.001\right)$ are performed by Student's $t$-test. Scale bar: $10 \mu \mathrm{m}$. 

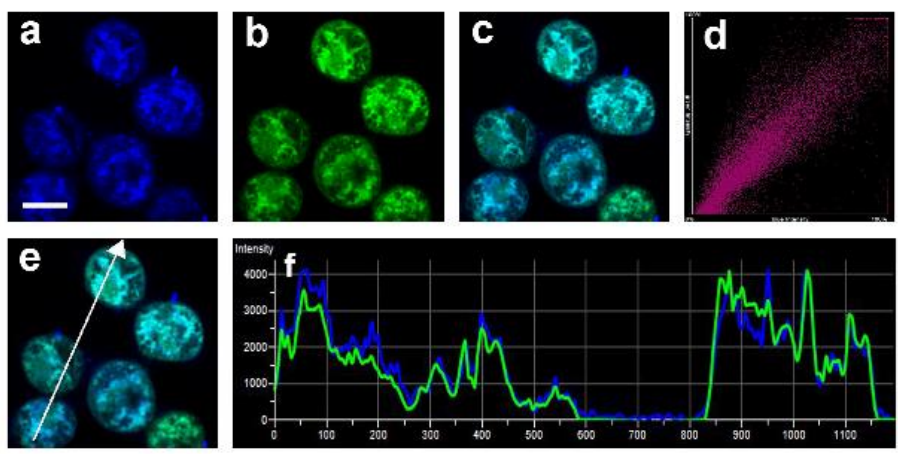

Figure S11. Colocalization experiments involving ZED and Mito-Tracker Green (MTG) in MCF-7 cells. Cells incubated in sequence with $5 \mu \mathrm{M}$ ZED for $10 \mathrm{~min}, 1 \mu \mathrm{M}$ MTG for $10 \mathrm{~min}$, and $50 \mu \mathrm{M}$ CCCP for $2 \mathrm{~h}$. Images for ZED (a) and MTG (b) were then recorded using excitation wavelengths of 405 and $488 \mathrm{~nm}$, and band-path emission filters at 417-477 and 499-529 nm, respectively. (c, e) Merged images of (a) and (b). (d) Colocalization scatter plot of (a) and (b). (f) Intensity profile of the white arrow in (e). Scale bar: $10 \mu \mathrm{m}$.
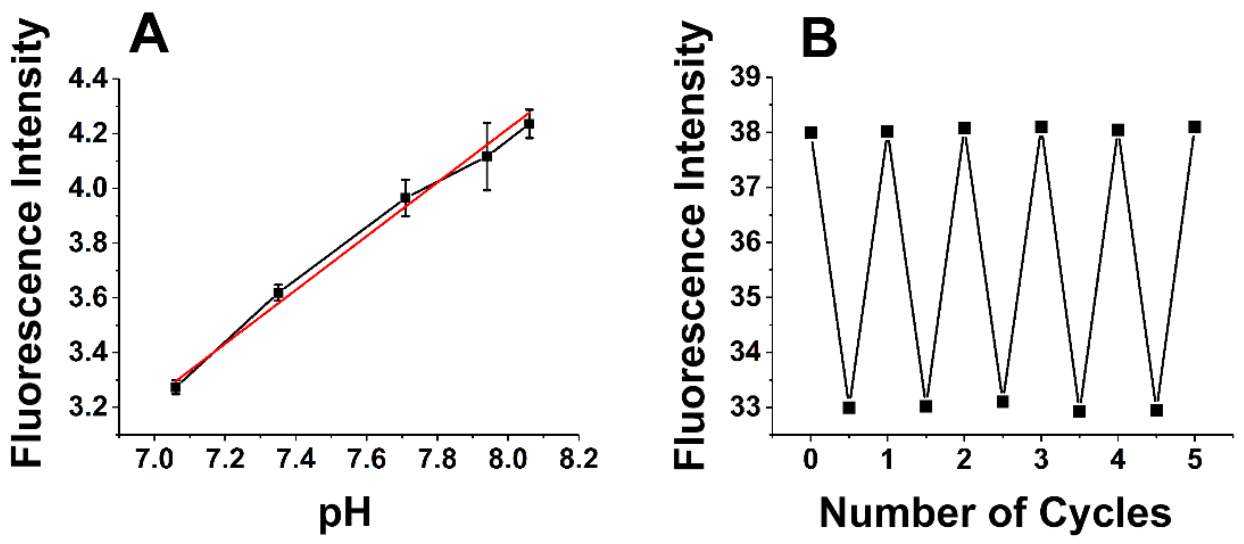

Figure S12. Fluorescent response of ZED-1 to pH in PBS buffers, excitation at $405 \mathrm{~nm}$. (A) The fluorescence intensities with $\mathrm{pH}$ from 7.06 to 8.06 . (B) The fluorescence reversibility of ZED-1 between $\mathrm{pH} 7.4$ and 8.0 . 

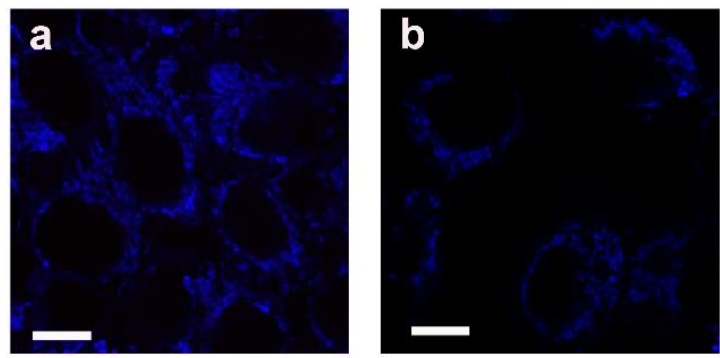

Figure S13. Confocal experiments involving ZED in MCF-7 cells. (a) Cells incubated with $5 \mu M$ ZED for 10 min. (b) Cells incubated with $5 \mu \mathrm{M}$ ZED for 10 min and then treated with $50 \mu \mathrm{M} \mathrm{CCCP} \mathrm{for} 20$ s. After that, CCCP was removed to regain $\Delta \psi_{\mathrm{m}}$. Images were recorded using excitation wavelength of $405 \mathrm{~nm}$, and band-path emission filter at 417-477 nm. Scale bar: $10 \mu \mathrm{m}$.
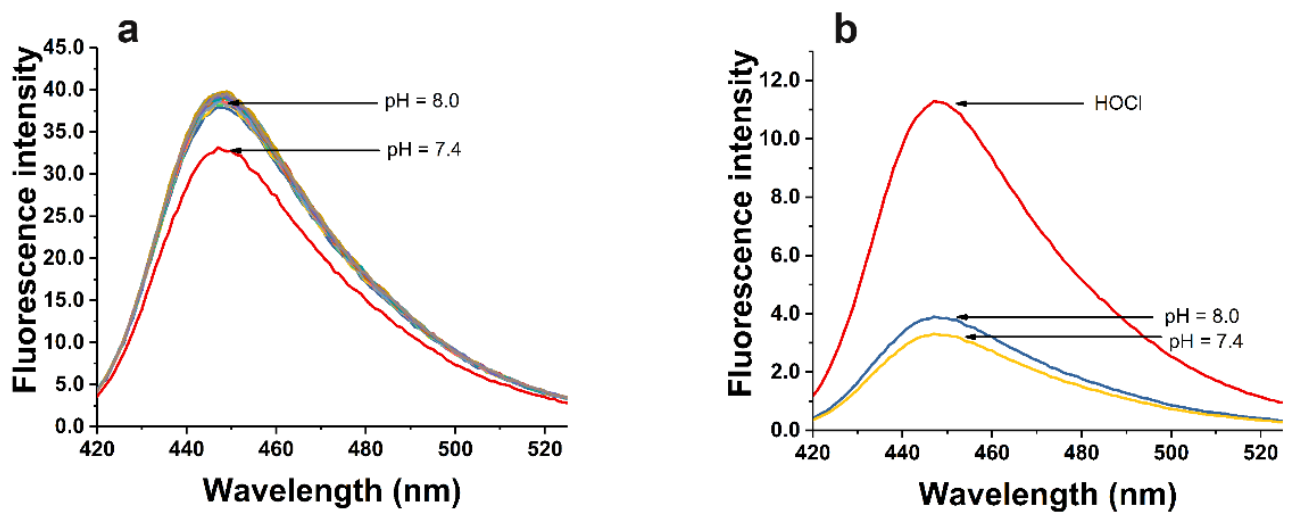

Figure S14. Fluorescence spectra of $5 \mu \mathrm{M}$ ZED-1 in PBS buffers toward various analytes: $10 \mu \mathrm{M}$ for ONOO, $\mathrm{HOCl}, \mathrm{H}_{2} \mathrm{O}_{2}, \mathrm{O}_{2}{ }^{-}$, t-BuOOH, $\cdot \mathrm{OH},{ }^{1} \mathrm{O}_{2}, \mathrm{NO} ; 100 \mu \mathrm{M}$ for amino acids: Cys, Hcy, GSH, Val, Tyr, Trp, Ser, Pro, Lys, Leu, His, Gly, Glu, Asp, Asn, Arg, Ala; $100 \mu \mathrm{M}$ for $\mathrm{Na}^{+}, \mathrm{K}^{+}, \mathrm{Ca}^{2+}, \mathrm{Mg}^{2+}$, $\mathrm{Cu}^{2+}, \mathrm{Fe}^{2+}, \mathrm{Zn}^{2+}, \mathrm{Cl}^{-}, \mathrm{NO}_{2}{ }^{-}, \mathrm{H}_{2} \mathrm{~S}, \mathrm{NO}_{3}{ }^{-}$; excitation at $405 \mathrm{~nm}$. All the analytes except for $\mathrm{HOCl}$ (a) and $\mathrm{HOCl}(\mathrm{b})$. The arrows indicate the fluorescence spectra of ZED-1 alone at pH values of 8.0 and 7.4, respectively. 

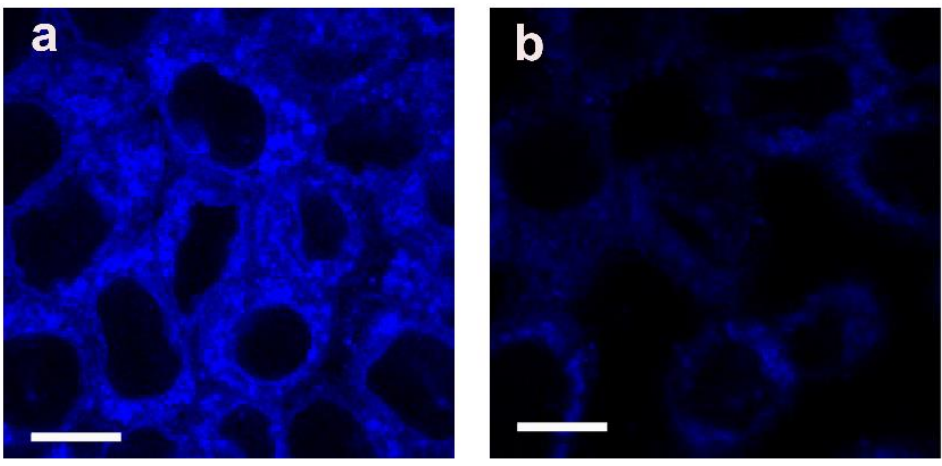

Figure S15. Confocal experiments involving ZED in MCF-7 cells. Cells incubated with $5 \mu M$ ZED for 10 min and then treated with CCCP in the absence (a) or presence (b) of cyclosporin A for $2 \mathrm{~h}$. Images were recorded using excitation wavelength of $405 \mathrm{~nm}$, and band-path emission filter at 417-477 nm. Scale bar: $10 \mu \mathrm{m}$.

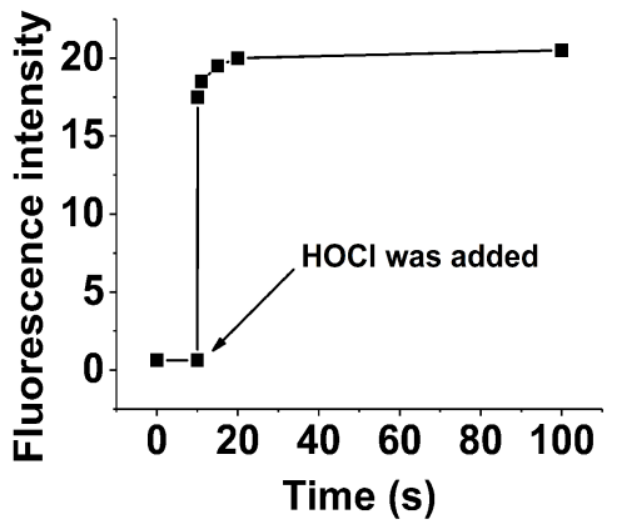

Figure S16. Fluorescent response of $5 \mu \mathrm{M}$ ZED-1 to $10 \mu \mathrm{M} \mathrm{HOCl}$ in PBS buffers at different time intervals, excitation at $543 \mathrm{~nm}$. 


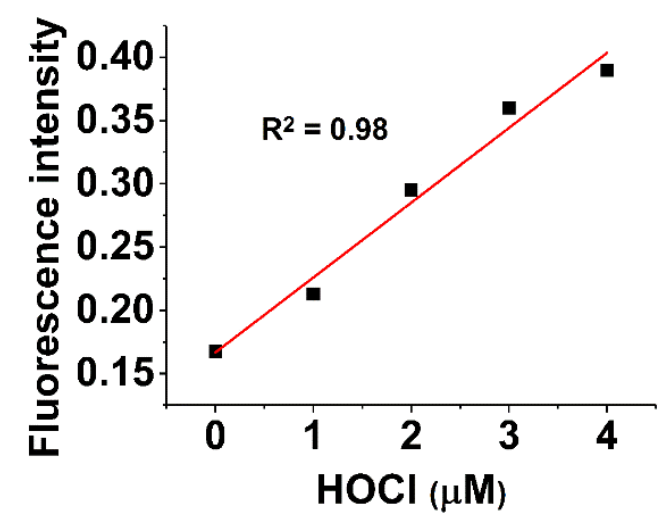

Figure S17. Fluorescent response of $5 \mu \mathrm{M}$ ZED-1 to $0-4 \mu \mathrm{M} \mathrm{HOCl}$ in PBS buffers (pH 8.0), excitation at $543 \mathrm{~nm}$.

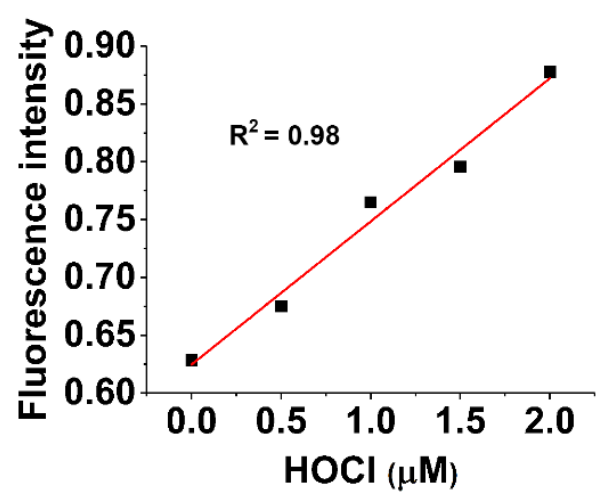

Figure S18. Fluorescent response of $5 \mu \mathrm{M}$ ZED to $0-2 \mu \mathrm{M} \mathrm{HOCl}$ in PBS buffers (pH 8.0), excitation at $543 \mathrm{~nm}$. 

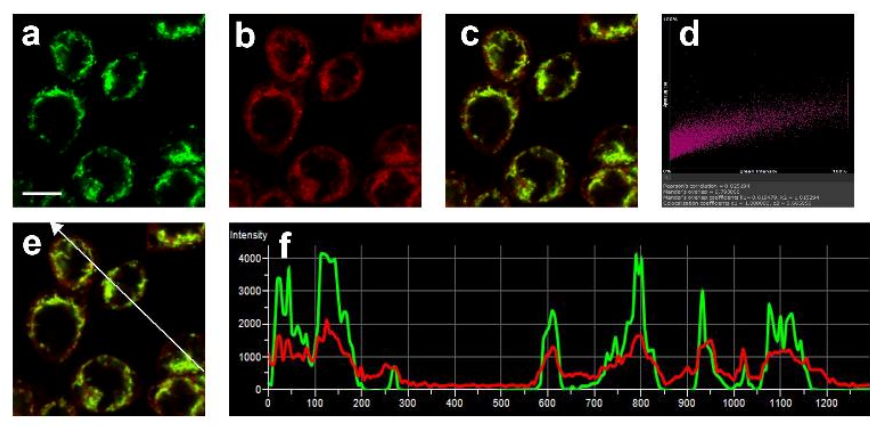

Figure S19. Colocalization experiments involving ZED and Mito-Tracker Green (MTG) in MCF-7 cells. Cells incubated in sequence with $5 \mu \mathrm{M}$ ZED for $10 \mathrm{~min}, 1 \mu \mathrm{M}$ MTG for $10 \mathrm{~min}$, and $80 \mu \mathrm{M}$ $\mathrm{HOCl}$ for $15 \mathrm{~min}$. Images for MTG (a) and ZED (b) were then recorded using excitation wavelengths of 488 and $543 \mathrm{~nm}$, and band-path emission filters at 499-529 and 553-618 nm, respectively. (c, e) Merged images of (a) and (b). (d) Colocalization scatter plot of (a) and (b). (f) Intensity profile of the white arrow in (e). Scale bar: $10 \mu \mathrm{m}$.
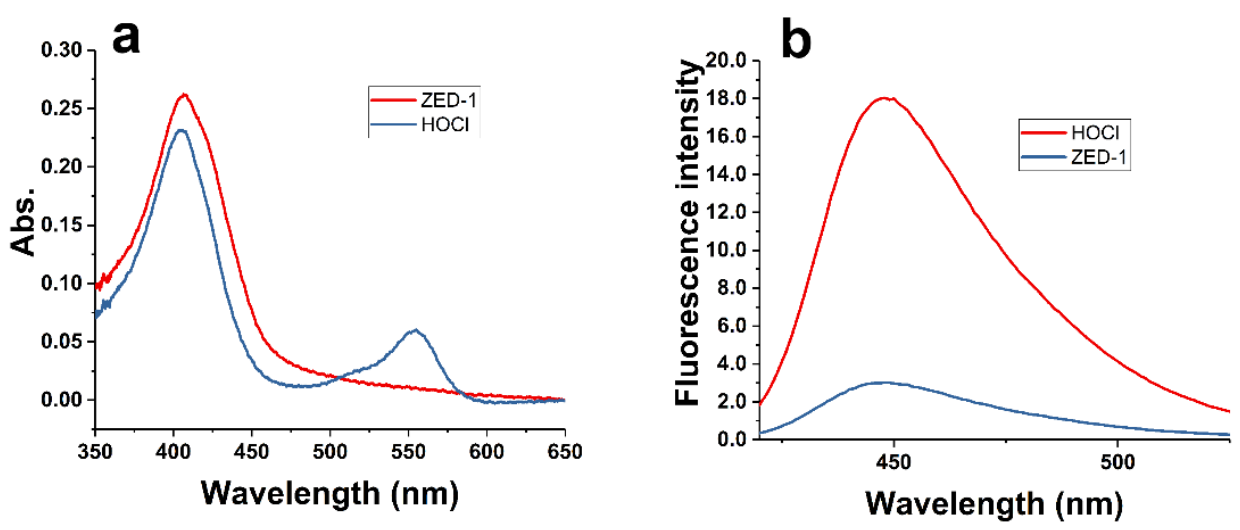

Figure S20. Absorbance and fluorescence spectra of $5 \mu \mathrm{M}$ ZED-1 alone or in the presence of 15 $\mu \mathrm{M} \mathrm{HOCl}$ in PBS buffers ( $\mathrm{pH} 8.0$ ). (a) The absorbance spectra. (b) The fluorescence spectra, excitation at $405 \mathrm{~nm}$. 

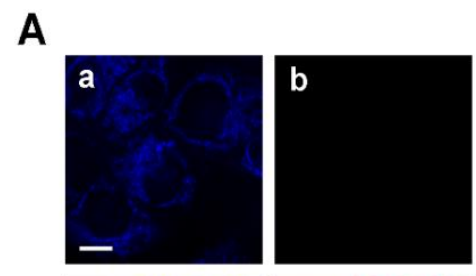

\section{B}

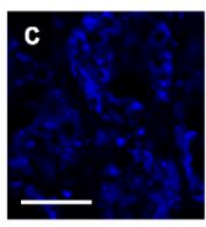

d
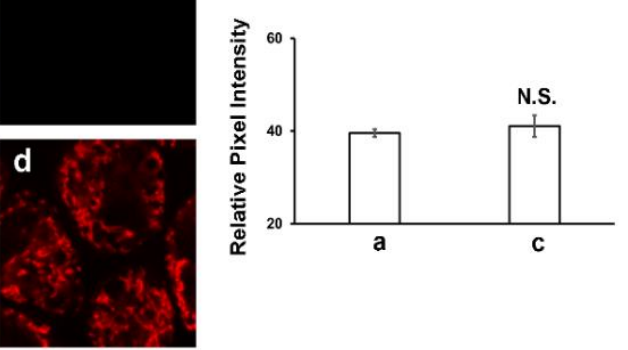

Figure S21. Fluorescence quenching experiments involving ZED and Mito-Tracker Red (MTR) in MCF-7 cells. (A) Images of the cells. (a, b) Cells incubated with $5 \mu$ M ZED for 10 min. (c, d) Cells incubated in sequence with $5 \mu \mathrm{M}$ ZED for $10 \mathrm{~min}$ and $200 \mathrm{nM}$ MTR for $10 \mathrm{~min}$. (a, c) and (b, d) were recorded using excitation wavelengths of 405 and $543 \mathrm{~nm}$, and band-path emission filters at 417-477 and 553-618 nm, respectively. (B) Relative pixel intensity of the related images in (A). The results are presented as mean \pm standard deviation $(n=3)$. The significant difference (N.S.: no significant difference) is performed by Student's $t$-test. Scale bar: $10 \mu \mathrm{m}$.
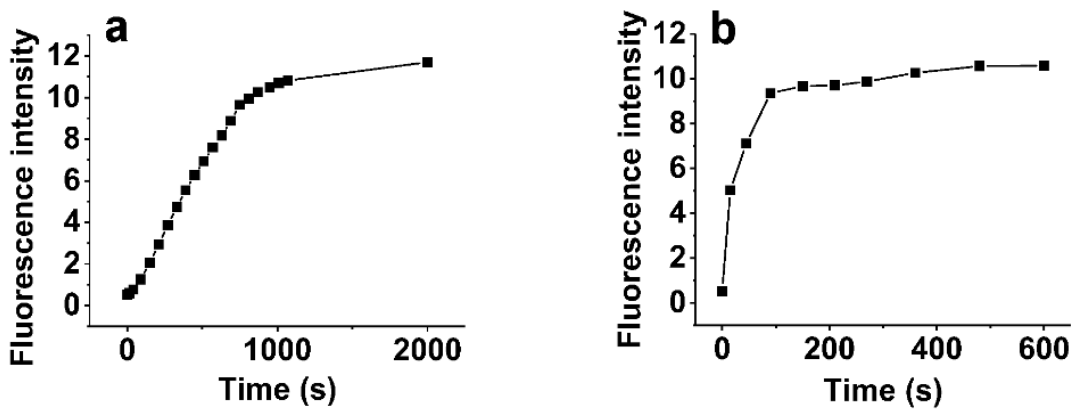

Figure S22. Fluorescent response of $5 \mu \mathrm{M}$ ZED to $2 \mathrm{mM}$ Cys/Hcy in PBS buffers $(\mathrm{pH}$ 8.0) at different time intervals, excitation at $488 \mathrm{~nm}$. (a) Hcy and (b) Cys. 


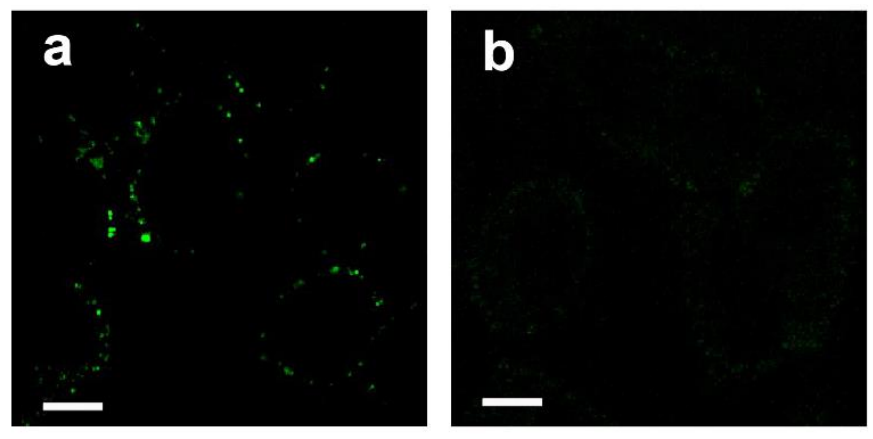

Figure S23. Fluorescent response of ZED to Cys/Hcy in A549 cells. (a) Cells incubated with $5 \mu M$ ZED for 10 min. (b) Cells pretreated with NEM and then incubated with $5 \mu M$ ZED for 10 min. Images were recorded using excitation wavelength of $488 \mathrm{~nm}$, and band-path emission filter at 499-529 nm. Scale bar: $10 \mu \mathrm{m}$. 


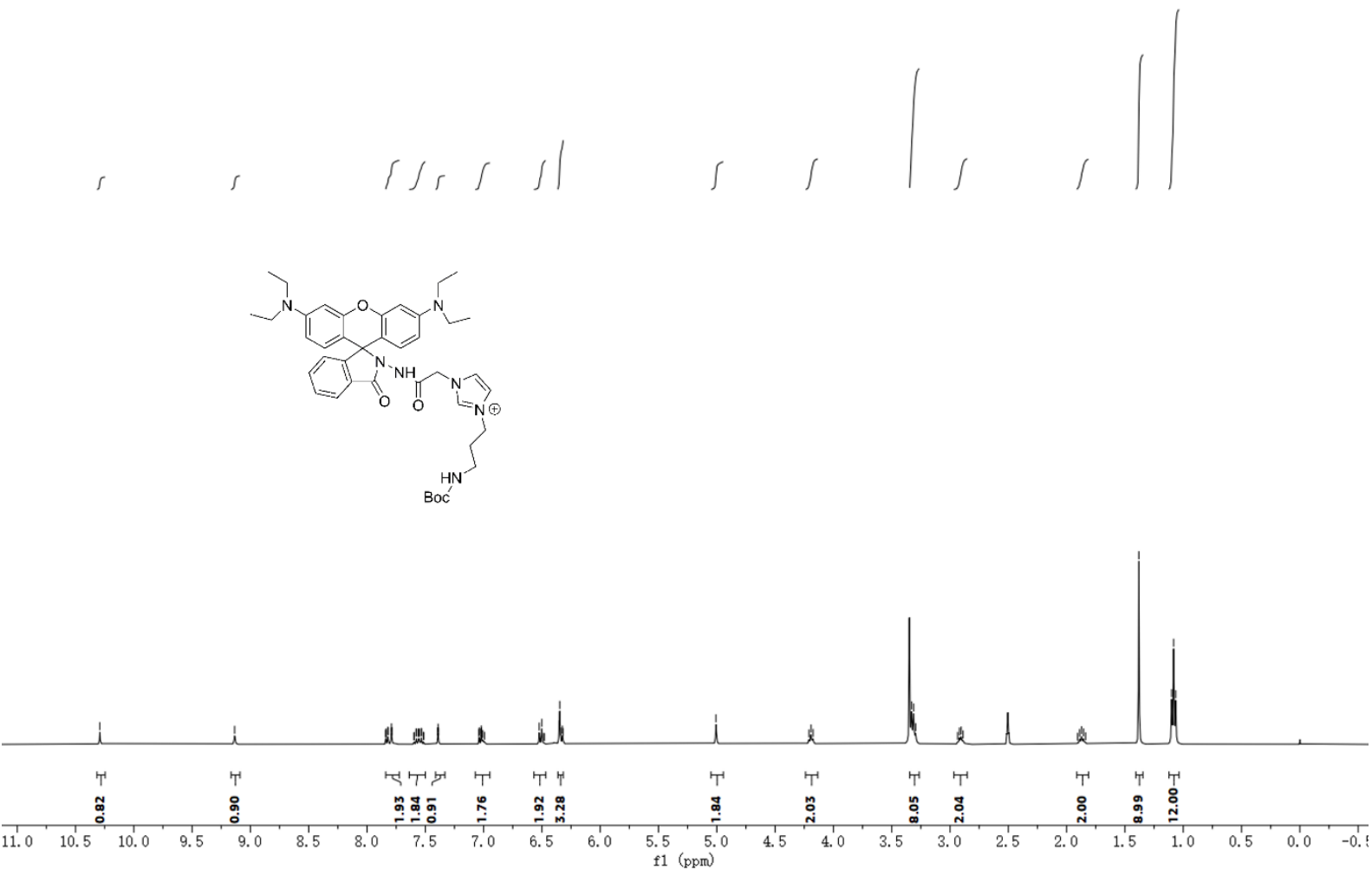

Figure S24. ${ }^{1} \mathrm{H}$ NMR spectrum of compound 1 in DMSO- $d_{6}$.

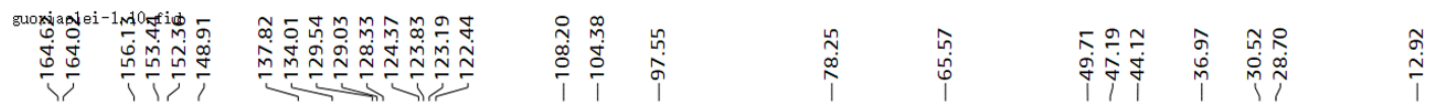
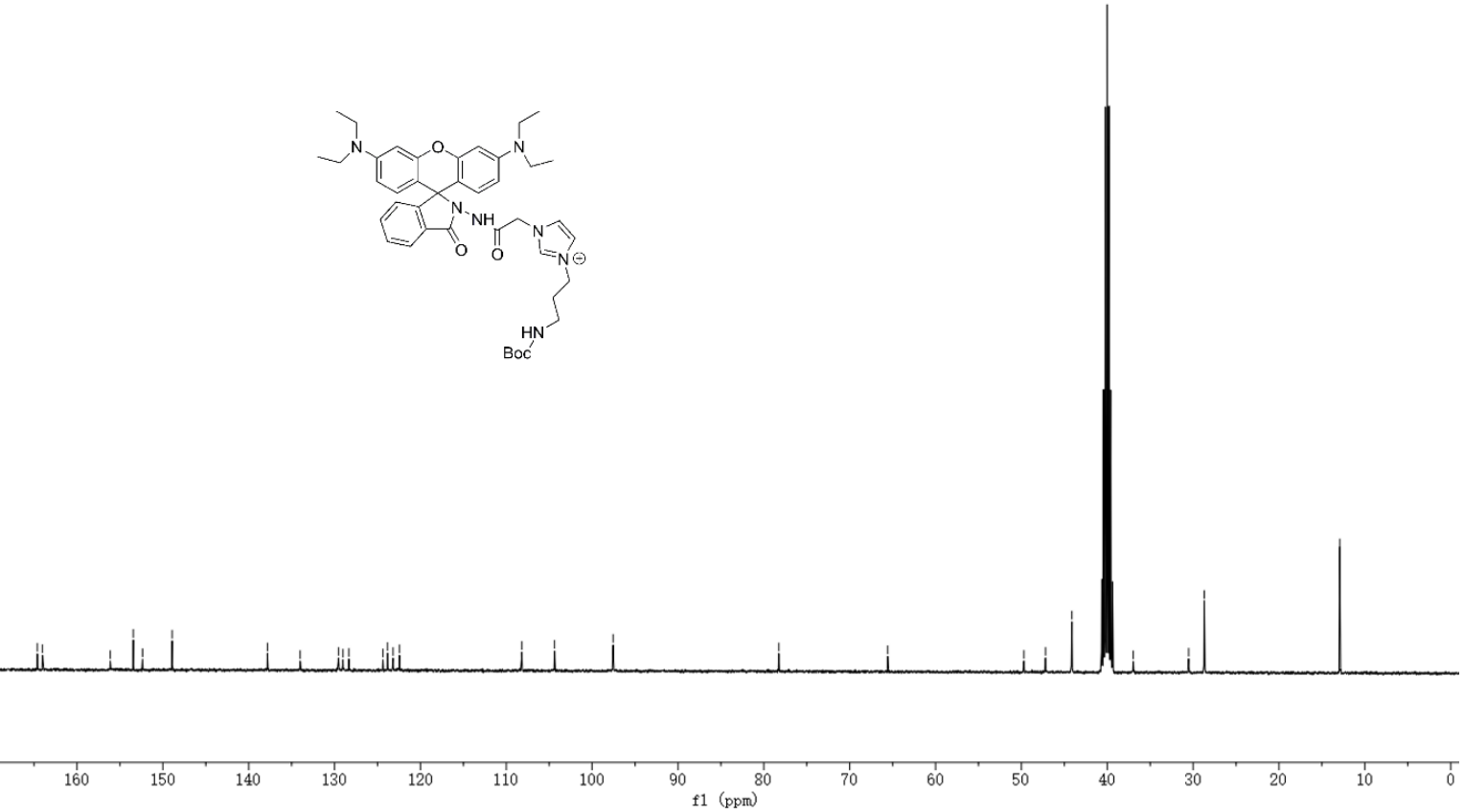

Figure S25. ${ }^{13} \mathrm{C}$ NMR spectrum of compound 1 in DMSO- $d_{6}$. 

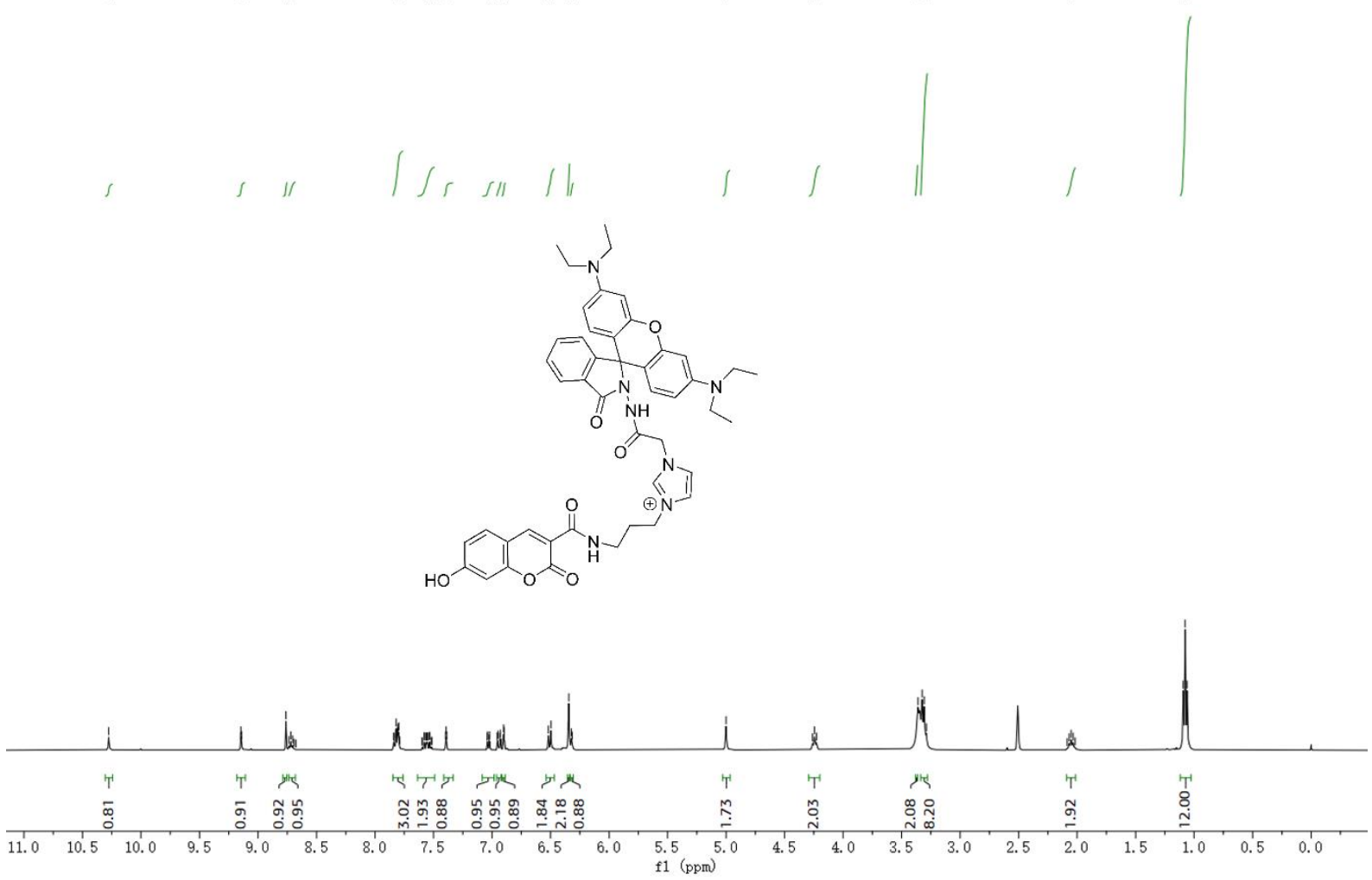

Figure S26. ${ }^{1} \mathrm{H}$ NMR spectrum of compound 3 in DMSO- $d_{6}$.

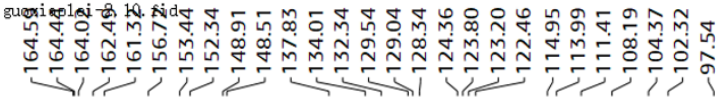

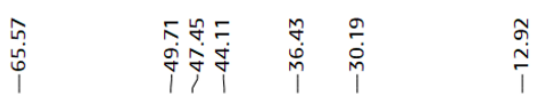

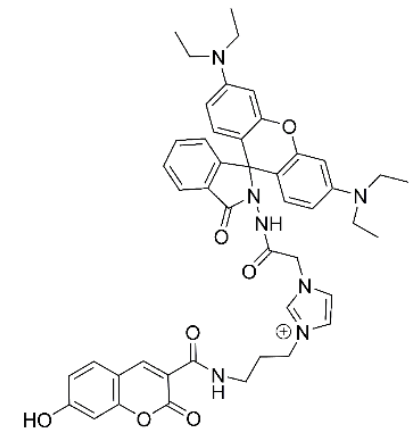

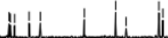

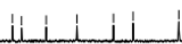

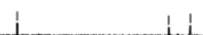

170

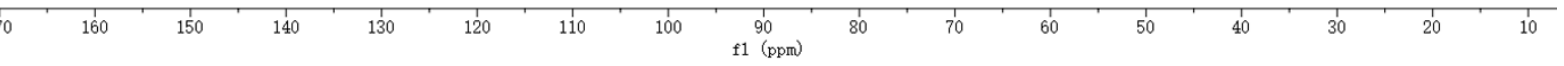

Figure S27. ${ }^{13} \mathrm{C}$ NMR spectrum of compound 3 in DMSO- $d_{6}$. 


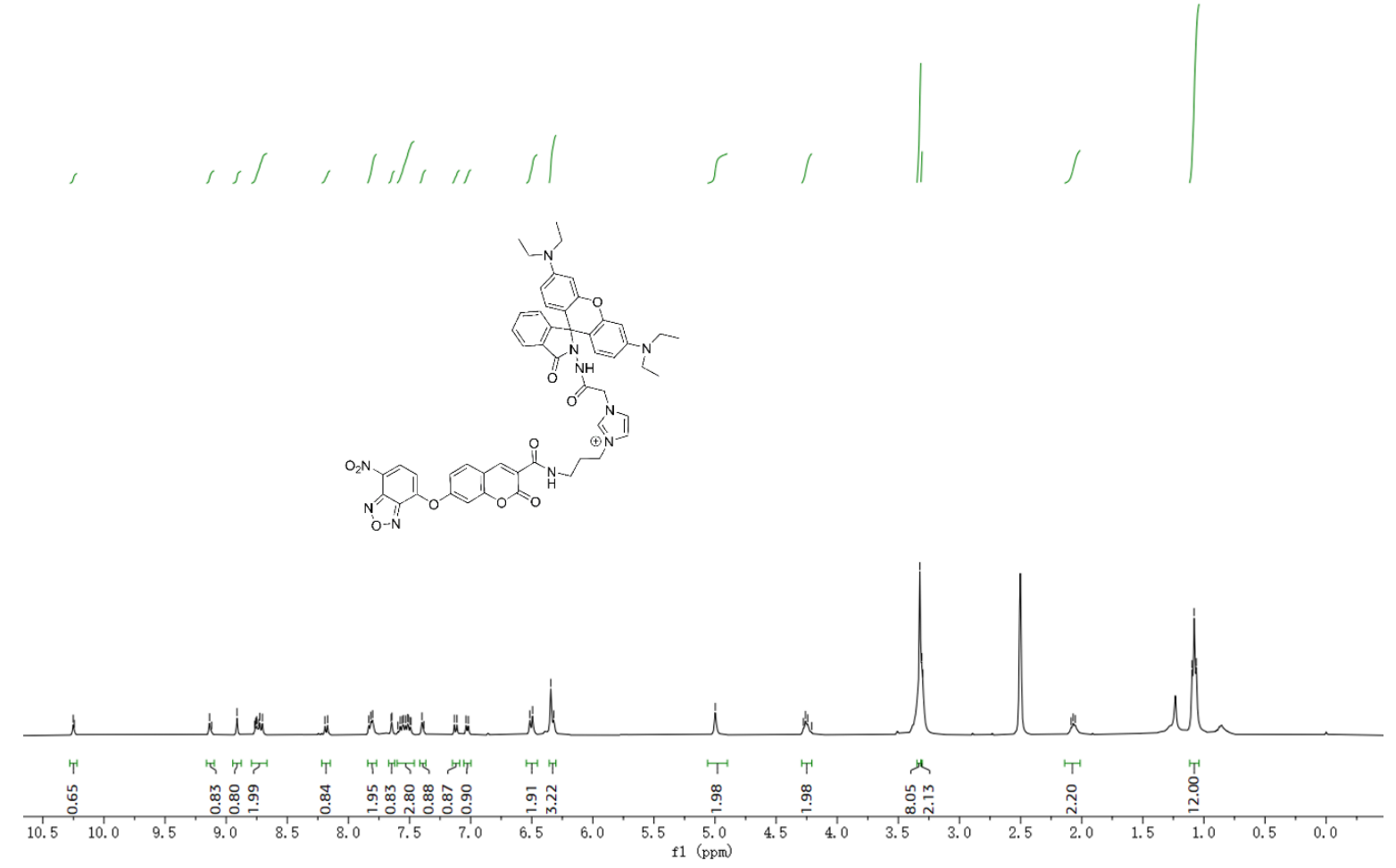

Figure S28. ${ }^{1} \mathrm{H}$ NMR spectrum of compound 4 in DMSO- $d_{6}$.

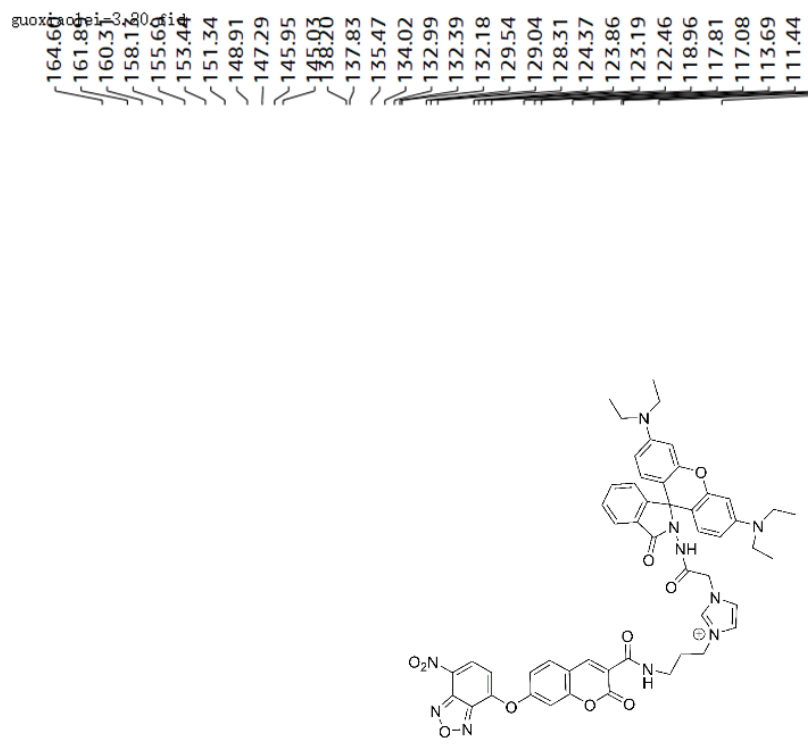

年

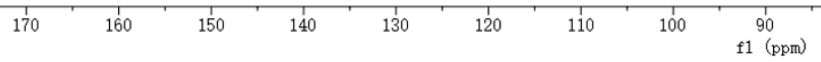

Figure S29. ${ }^{13} \mathrm{C}$ NMR spectrum of compound 4 in DMSO- $d_{6}$. 


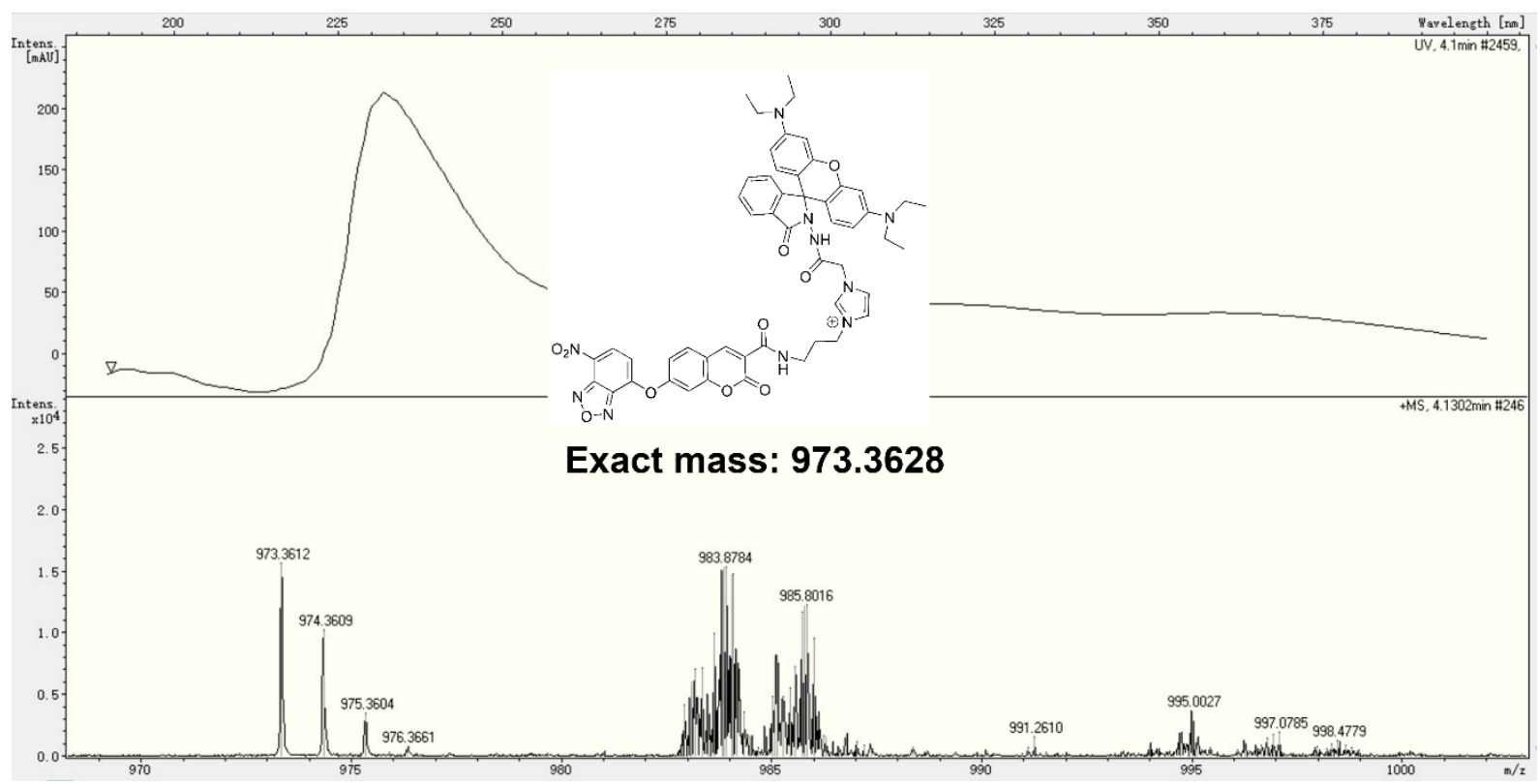

Figure S30. Mass spectrum of compound 4.

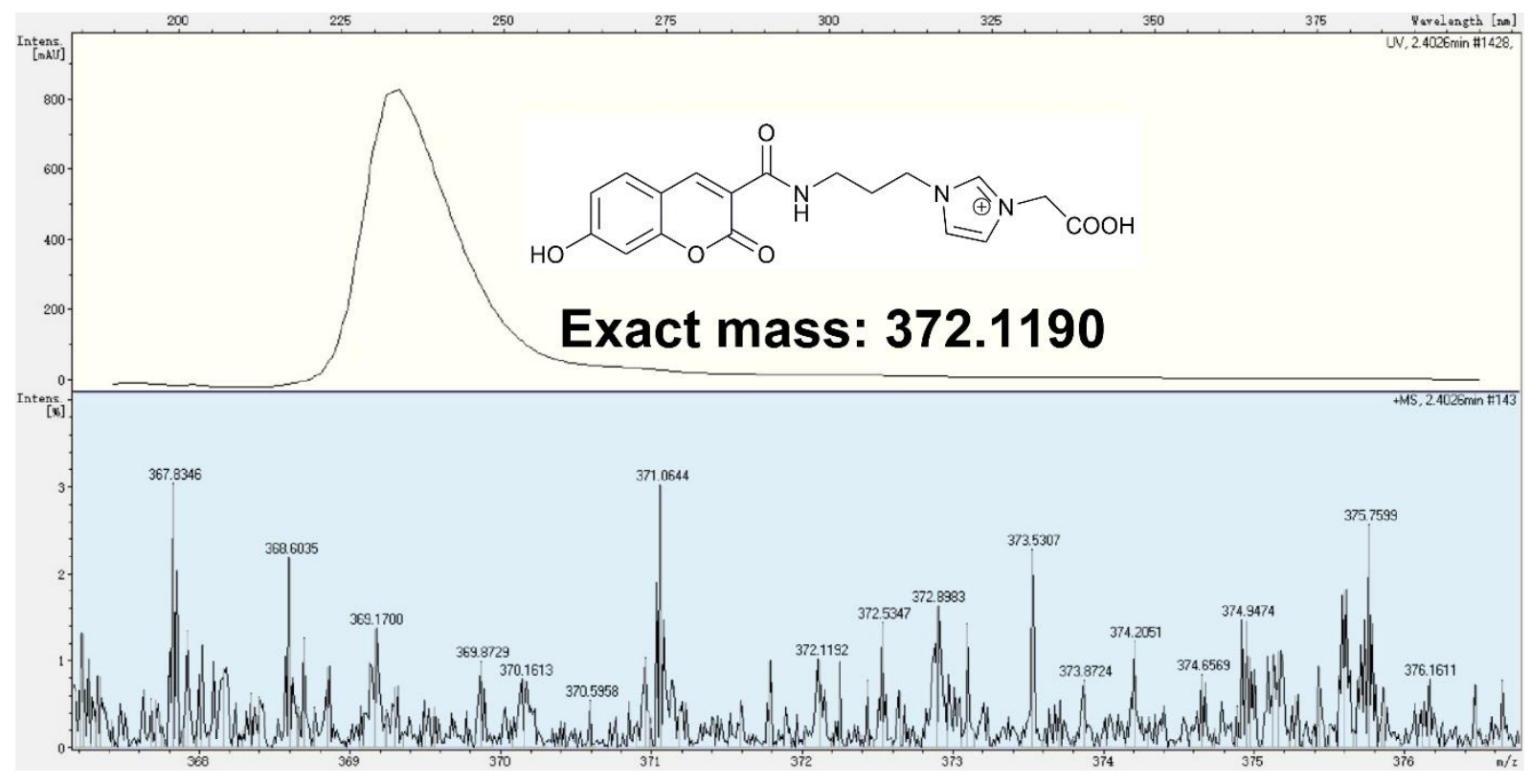

Figure S31. Mass spectrum of ZED-2. 